\title{
ABO Blood Groups and Infantile Hypertrophic Pyloric Stenosis
}

\author{
J. A. DODGE,* M.B., B.CH., M.R.C.P.ED., D.C.H.
}

Brit. med.F., 1967, 4, 781-782

An association between blood group $A$ and cancer of the stomach was first reported by Aird, Bentall, and Fraser Roberts (1953). Further associations between blood groups and gastrointestinal disorders have since been described (Clarke, 1964a). This paper reponts an investigation into the ABO blood group distribution and salivary secretor status of patients with infantile hypertrophic pyloric stenosis.

\section{Material}

The ABO groups of 303 patients with infantile hypertrophic pyloric stenosis were determined as part of a follow-up study. In all instances the diagnosis had been confirmed at operation, and all patients were resident in Belfast or its immediate environs at that time.

Information concerning the distribution of the $\mathrm{ABO}$ blood groups in Belfast was obtained from the Serological Population Genetics Laboratory (A. C. Kopeć, personal communication, 1967) and used for control purposes.

The salivary secretor status of 288 patients with infantile hypertrophic pyloric stenosis was investigated. Control data were obtained from 96 children admitted to hospital for tonsillectomy or adenoidectomy and from 435 children attending school dental clinics in Belfast.

\section{Methods}

Blood samples were obtained by venepuncture except in a small number of infants, when capillary blood obtained by heel stab was used. In all cases a full explanation was given to the parents, and in no instance was permission for blood sampling refused. $\mathrm{ABO}$ blood groups were determined by the tube method.

Samples of saliva were examined for the presence of $\mathrm{ABH}$ blood group substances. The children were asked to rinse their mouths with water before saliva was collected into plastic specimen jars and transferred to test-tubes. In the case of infants saliva was aspirated gently with a 2-ml. syringe. The tubes were partly immersed in a boiling water-bath for 10 to 20 minutes before being stoppered and stored in a refrigerator at $4^{\circ} \mathrm{C}$. until testing, which was usually within 24 hours. Saliva specimens were tested for the presence of $A, B$, and $H$ substances by the method of Dunsford and Bowley (1955). The anti-A and anti-B sera were provided by the N.I. Blood Transfusion Service, whose laboratories also prepared and extracted anti- $\mathrm{H}$ from the seeds of Ulex europaeus. Absence of inhibition of agglutination of $\mathrm{O}$ cells by anti-H serum diluted 1 in 8 , in the presence of a 1 in 2 dilution of saliva, was accepted as a negative result. (This dilution was found to be the most satisfactory which could give a clear-cut result on microscopical examination.)

After the first 70 tests had been performed checking for A and $B$ substances was omitted on most occasions because it was found that in all cases of secretion of $A$ or $B$ substances $H$ sub-

* Department of Child Health, the Queen's University of Belfast. Northern Ireland. stance could also be detected. Since the concentration of $\mathrm{H}$ substance in the saliva of group B secretors is often lower than in those of group O (Clarke, McConnell, and Sheppard, 1960), all non-secretors of known blood group B were reviewed a second time and their salivas examined for the presence of both $\mathrm{B}$ and $\mathrm{H}$ antigens; no trace of either could be detected in any instance.

\section{Results}

The distribution of $\mathrm{ABO}$ blood groups among 303 patients with infantile hypertrophic pyloric stenosis compared with controls is shown in Table I. It is evident that there were an unexpectedly large number of patients of blood group B in this series and a correspondingly small representation of patients of blood group A. These findings are statistically significant $(P=0.001)$. Group $O$ patients formed approximately the same proportion of the series as of the controls, and the slight excess of group $\mathrm{AB}$ patients was too small in actual numbers to justify further consideration. The relative incidence of pyloric stenosis in persons of groups $\mathrm{O}$ and $\mathrm{B}$ compared with group $\mathrm{A}$ is given in Table II. The $\chi^{2}$ was calculated by the method of Woolf (1955) and is again statistically significant.

TABLB I.-Distribution of ABO Blood Groups in 303 Patients with Infantile Hypertrophic Pyloric Stenosis Compared with Distribution in Controls

\begin{tabular}{c|c|c|c|c}
\hline \multirow{2}{*}{ Group } & \multicolumn{2}{|c}{ Patients } & \multicolumn{2}{c}{ Controls } \\
\cline { 2 - 5 } \cline { 3 - 4 } & Total No. & Percentage & Total No. & Percentage \\
\hline O & 170 & 56.11 & 15,269 & 55.01 \\
B & 76 & 25.08 & 9,168 & 33.03 \\
AB & 45 & 14.85 & 2,624 & 9.45 \\
Total & 12 & 3.96 & 696 & 2.51 \\
\hline 303 & 100 & 27757 & 100 \\
\hline
\end{tabular}

$\chi^{2}=18 \cdot 228$. D.F. $=3$. $P<0.001$

TABLE II.-Relative Incidence of Infantile Hypertrophic Pyloric Stenosis in Children of Groups $O$ and $B$, Compared with Incidence of 1.0 in Persons of Group $A$

\begin{tabular}{|c|c|c|c|}
\hline Group & Relative Incidence & $x^{2}$ & $\mathbf{P}$ \\
\hline$\underset{\mathrm{B}}{\mathrm{O}}$ & $\begin{array}{l}1 \cdot 40 \\
2 \cdot 10\end{array}$ & $\begin{array}{r}5 \cdot 95 \\
15 \cdot 27\end{array}$ & $\begin{aligned} 0.02 & >\mathrm{P}>0.01 \\
& <0.001\end{aligned}$ \\
\hline
\end{tabular}

The incidence of salivary non-secretors was lower than expected, but this is not significant $(0.1<\mathrm{P}<0.2)$ (Table III). The secretor status of the blood group controls is not known, so Table IV gives a calculated expected incidence of each blood group and secretor type combination, compared with the observed incidence in infantile pyloric stenosis, but no claim is made that these results are statistically valid.

TABLE III.-Distribution of Secretor Status in 288 Patients with Infantile Hypertrophic Pyloric Stenosis Compared with 531 Controls

\begin{tabular}{|c|c|c|c|c|c|c|}
\hline & & & Patients & Percentage & Controls & Percentage \\
\hline $\begin{array}{l}\text { Secretor } \\
\text { Non-secretor }\end{array}$ & $\therefore$ & $\begin{array}{l}\cdots \\
\cdots\end{array}$ & $\begin{array}{r}226 \\
62\end{array}$ & $\begin{array}{l}78 \cdot 47 \\
21 \cdot 53\end{array}$ & $\begin{array}{l}390 \\
141\end{array}$ & $\begin{array}{l}73.45 \\
26.55\end{array}$ \\
\hline Total & . & . & 288 & 100 & 531 & 100 \\
\hline
\end{tabular}

$x^{2}=2.52$. D.F. $=1 . \quad 0.1<P<0.2$ 
TABLE IV.-Distribution of ABO Blood Groups and Secretor Status in 288 Patients with Infantile Hypertrophic Pyloric Stenosis Compared with Expected Incidence in the Control Population*

\begin{tabular}{|c|c|c|c|c|}
\hline \multicolumn{3}{|c|}{$\begin{array}{l}\text { Blood Group and } \\
\text { Secretor Type }\end{array}$} & $\begin{array}{l}\text { Expected Percentage } \\
\text { in Controls }\end{array}$ & $\begin{array}{c}\text { Observed Percentage } \\
\text { in I.H.P.S. }\end{array}$ \\
\hline $\begin{array}{l}\text { Group O secretor .. } \\
\text { Group O non-secretor } \\
\text { Group A secretor .. } \\
\text { Group A non-secretor } \\
\text { Group B secretor .. } \\
\text { Group B non-secretor } \\
\text { Group AB secretor } \\
\text { Group AB non-secretor }\end{array}$ & $\begin{array}{l}\because \\
\because \\
\because \\
\because \\
\therefore\end{array}$ & $\begin{array}{l}\because \\
\because \\
\because \\
\because \\
\because \\
\therefore\end{array}$ & $\begin{array}{r}40 \cdot 40 \\
14 \cdot 61 \\
24 \cdot 26 \\
8 \cdot 77 \\
6 \cdot 94 \\
2.51 \\
1.85 \\
0.66\end{array}$ & $\begin{array}{r}42.71 \\
11.81 \\
21.88 \\
4.17 \\
10.76 \\
4.51 \\
3.12 \\
1.04\end{array}$ \\
\hline
\end{tabular}

- Blood group data were obtained from the Serological Population Genetics Laboratory. As the secretor status of these donors was not known, the expected incidence of each blood group and secretor/non-secretor combination has been calculated by using the observed secretor/non-secretor ratio in the child controls
referred to in Table III.

\section{Discussion}

It has been stated that infants with hypertrophic pyloric stenosis have a high incidence of peptic ulcer in later life (Bendix and Necheles, 1947 ; Belding and Kernohan, 1953 ; Hecker, Wenz, and Brückner, 1966), though control data are difficult to obtain. If this were so one might expect to find an increased incidence of blood group $\mathrm{O}$ among babies with pyloric stenosis, such as is seen in adult ulcer patients. Indeed, it is possible that the pyloric hypertrophy develops in association with a juxtapyloric ulcer occurring in the neonatal period, for there is no apparent reason why newborn infants should not be equally subject to peptic ulcer as adults (Polacek and Ellison, 1966). Burge, Gill, and Lewis (1963) suggest that hypertrophic pyloric stenosis in adults is always related to ulceration in or near the pylorus, a view which was earlier put forward by Golden (1937).

The present series certainly demonstrates an excess of group $\mathrm{O}$ patients when compared with those of group $\mathrm{A}$, of the same order as that seen in several series of duodenal ulcer patients (Clarke, 1964b). However, this apparent excess of group $O$ patients is actually a reduced incidence of persons of group $A$, a deficiency which is largely compensated by the marked increase in the proportion of group B patients in the series. Thus group A may be regarded as in some way protecting against the development of infantile pyloric stenosisor, alternatively, both group $\mathrm{O}$ and group $\mathrm{B}$ infants are at greater risk than those of group A (Table II). Though the group $O$ babies would also have a theoretically greater chance of developing an ulcer, no association between group B and peptic ulcer has been reported.

Non-secretors of group $O$ are particularly liable to develop peptic ulcers (Clarke, Price Evans, McConnell, and Sheppard, 1959). In this series secretor status appears to be unrelated to the occurrence of pyloric stenosis.

The blood group distribution seen in infantile hypertrophic pyloric stenosis may be compared with that found in relation to the production of alkaline phosphatase by the gut after a fatty meal. It has been shown that persons of groups $O$ and $B$ produce more of this type of alkaline phosphatase than those of groups AB and A (Arfors, Beckman, and Lundin, 1963a). Thus individuals of groups $\mathrm{O}$ and $\mathrm{B}$ not only produce more intestinal alkaline phosphatase than those of group $A$ but would also appear to have a greater susceptibility to infantile pyloric stenosis. It is known that secretors of $\mathrm{ABH}$ substances produce more intestinal alkaline phosphatase than non-secretors of the same blood group (Arfors, Beckman, and Lundin, 1963b). Thus secretors of groups $\mathrm{O}$ and $\mathrm{B}$ produce most alkaline phosphatase, followed by $\mathrm{O}$ and $\mathrm{B}$ non-secretors, with group $\mathrm{A}$ non-secretors producing least of all. Though not statistically significant, such evidence as this present study provides does suggest that (except in the case of group A) salivary $\mathrm{ABH}$ secretors are at greater risk of developing infantile pyloric stenosis than nonsecretors. The series is too small to allow firm conclusions to be drawn in this respect, and no information is yet available about the secretion of alkaline phosphatase in pyloric stenosis.

\section{Summary}

Analysis of the ABO blood groups of 303 patients with infantile hypertrophic pyloric stenosis showed a significantly low incidence of group A compared with controls. The blood group distribution is discussed in relation to the quantitative differences in intestinal alkaline phosphatase found in persons of different $\mathrm{ABO}$ groups.

Investigation of salivary $\mathrm{ABH}$ secretor status showed no significant difference between patients with infantile pyloric stenosis and controls.

I thank the consultant paediatricians and surgeons of the Royal Belfast Hospital for Sick Children, Belfast City Hospital, and the Ulster Hospital for allowing me to review patients under their care ; Professor I. J. Carré for his helpful advice and encouragement; Dr. M. C. Huth and Mr. T. Wilson for supplying anti-H serum; Dr. J. M. Bridges for laboratory facilities and assistance; Dr. J. D. Merrett for advice on statistical methods; and Dr. A. L. Walby, Schools Medical Officer, and the dental surgeons of the School Health Service, Belfast, for providing control specimens of saliva.

\section{REFERENCES}

Aird, I., Bentall, H. H., and Roberts, J. A. F. (1953). Brit. med. F., 1, 799.

Arfors, K. E., Beckman, L., and Lundin, L. G. (1963a). Acta genet. (Basel), 13, 89 .

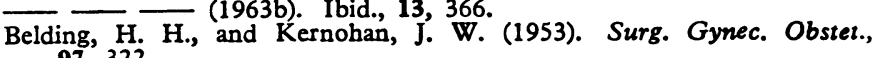
97, 322 .

Bendix, R. M., and Necheles, H. (1947). 7. Amer. med. Ass., 135, 331. Burge, H., Gill, A. M., and Lewis, R. H. (1963). Lancet, 1, 73.

Clarke, C. A. (1964a). Genetics for the Clinician, 2nd ed., p. 117 Oxford. (1964b). Ibid., p. 106.

- McConnell, R. B., and Sheppard, P. M. (1960). Ann. hum. Genet.,

24, 295 . Price med. ₹., 1, 603 .

Dunsford, I., and Bowley, C. C. (1955). Techniques in Blood Grouping, p. 157. Edinburgh.

Golden, R. (1937). F. Amer. med. Ass., 109, 1497.

Hecker, W. C., Wenz, W., and Brückner, I. (1966). Mschr. Kinderheilk., 114,60 .

Polacek, M. A., and Ellison, E. H. (1966). Amer. Y. Surg., 111, 777.

Woolf, B. (1955). Ann. hum. Genet., 19, 251 